\title{
A herbicide resistance risk assessment for weeds in maize in New Zealand
}

\author{
Zachary Ngow ${ }^{1,2^{*}}$, Trevor K. James ${ }^{1}$ and Christopher E. Buddenhagen ${ }^{1 *}$ \\ ${ }^{1}$ AgResearch, Ruakura Research Centre, Private Bag 3123, Hamilton 3240, New Zealand \\ ${ }^{2}$ School of Science, University of Waikato, Hamilton, 3216, New Zealand \\ *Corresponding authors: zacharyngow@gmail.com; zachary.ngow@agresearch.co.nz; \\ chris.buddenhagen@agresearch.co.nz
}

(Original submission received 27 April 2021; accepted in revised form 7 November 2021)

\begin{abstract}
Despite an extensive history of research into herbicide resistance in New Zealand maize, some aspects remain understudied. Herbicide resistance was first detected in New Zealand in the 1980s in maize crops, with atrazine resistance in Chenopodium album L. and Persicaria maculosa Gray. Since then, Chenopodium album has also developed resistance to dicamba, and in the last five years Digitaria sanguinalis (L.) Scop. populations have been reported to be resistant to nicosulfuron. Here we estimate the risk of herbicide resistance arising in 39 common maize weeds. A list of weeds associated with maize was generated, omitting uncommon weeds and those that grow outside of the maize growing season. Weeds were ranked for their risk of evolving herbicide resistance with a scoring protocol that accounts for the specific herbicides used in New Zealand maize. Seven weed species were classified as having a high risk of developing herbicide resistance: Echinochloa crus-galli (L.) P.Beauv., Chenopodium album, Eleusine indica (L.) Gaertn., Xanthium strumarium L., Amaranthus powellii S.Watson, Solanum nigrum L. and Digitaria sanguinalis. Seventeen species were classed as moderate risk, and 15 were low risk. Herbicide classes associated with more resistant species were classed as high risk,these included acetohydroxy acid synthase inhibitors and photosystem-II inhibitors. Synthetic auxins had a moderate risk but only two herbicides in this class (dicamba and clopyralid) are registered for maize in New Zealand. Other herbicide mode-of-action groups used in maize were low risk. We recommend outreach to farmers regarding weed-control strategies that prevent high-risk species from developing resistance. Highrisk herbicide groups should be monitored for losses of efficacy. Resistance surveys should focus on these species and herbicides.
\end{abstract}

Keywords Zea mays, silage, agricultural chemicals, summer weeds

\section{INTRODUCTION}

Maize (Zea mays L.) is a major crop in New Zealand, principally grown for livestock feed as silage or grain (Booker 2009). In 2018, sales of grain and silage maize were estimated to be $\$ 267$ million (Robertson \& Hurren 2019). Approximately 58,000 hectares produced 1.2 million tonnes of dry matter of silage, and 15,000 hectares of maize were harvested to produce 180 thousand tonnes of grain in 2020 (AIMI 2020). Maize is grown primarily in the warmer parts of New Zealand, with most of the production in Waikato. Yields have steadily increased over the last 25 years (Morris et al. 2016) and are among the highest in the world (FAO 2021). In maize, weeds are estimated to have the potential to cause yield losses up to $40 \%$, which is more than the sum of the potential yield loss caused by pests and diseases (Oerke 2006); thus, weed control offers the most cost-effective plant-protection measure. Early-season weed control is critical for the establishment and growth of young plants (Page et al. 2012). To control weeds, a standard recommended herbicide programme (see: FAR 2020) would commonly use a pre-emergent residual herbicide (e.g., acetochlor, pendimethalin, saflufenacil, atrazine) followed by a post-emergent herbicide (e.g., nicosulfuron, topramezone, mesotrione, atrazine). Details of registered herbicides are provided in Table 1 . Two synthetic auxin herbicides dicamba and clopyralid are used specifically for broadleaf weeds. Glyphosate was not classed as a maize herbicide in our study, as glyphosate-tolerant maize cultivars are not grown in New Zealand. In silage maize, there is usually a winter rotation (e.g., sowing of Lolium multiflorum Lam. or Avena sativa L.) that needs to be terminated with glyphosate prior to planting. Following a grain-maize crop, land will usually be left fallow over winter, but weeds are usually controlled similarly with an application of glyphosate pre-planting. Soil is typically cultivated pre-planting but strip-till and no-till techniques are increasingly being adopted. Herbicides are the most widely used method of weed control, but some are becoming less effective with the evolution of herbicideresistant weeds.

Resistance-conferring mutations arise rarely and selection occurs instantaneously on sprayed weeds; with successive generations and treatments plants with resistance-conferring mutations preferentially reproduce 
Table 1 Herbicides registered for use in maize crops in New Zealand, adapted from Harrington and James (2020). Herbicide modes of action are grouped by their Herbicide Resistance Action Committee (HRAC) classification.

\begin{tabular}{|c|c|c|c|c|}
\hline HRAC Group & Mode of Action & Chemical group & Active ingredient & Application \\
\hline \multirow[t]{3}{*}{2} & AHAS Inhibitor & triazolopyrimidine & nicosulfuron & post \\
\hline & & sulfonylurea & halosulfuron & post \\
\hline & & & flumetsulam & post \\
\hline \multirow[t]{3}{*}{5} & PS-II inhibitor & triazine & atrazine & pre/post \\
\hline & & & cyanazine & pre/post \\
\hline & & & terbuthylazine & pre/post \\
\hline 5 & & triazinone & metribuzin & pre/post \\
\hline 5 & & substituted urea & linuron & pre/post \\
\hline 5 & & nitrile & bromoxynil & post \\
\hline 14 & PPO inhibitor & pyrimidinedione & saflufenacil & pre \\
\hline \multirow[t]{2}{*}{27} & HPPD inhibitor & triketone & mesotrione & pre/post \\
\hline & & pyrazole & topramezone & post \\
\hline 3 & microtubule assembly inhibitor & dinitroaniline & pendimethalin & pre \\
\hline \multirow[t]{5}{*}{15} & VLCFA synthesis inhibitor & chloroacetamide & acetochlor & pre \\
\hline & & & alachlor & pre \\
\hline & & & dimethenamid-P & pre \\
\hline & & & s-metolachlor & pre \\
\hline & & & propachlor & pre \\
\hline 4 & synthetic auxin & benzoic & dicamba & post \\
\hline 4 & & pyridine & clopyralid & post \\
\hline
\end{tabular}

to become increasingly dominant in the population (Délye et al. 2013). Globally there are 61 herbicide resistant weed species in maize with 323 unique cases (species $\times$ modeof-action; Heap 2021); meaning that $20 \%$ of all herbicide resistance cases have been documented in maize. Three species have developed resistance in New Zealand maize: Persicaria maculosa Gray, Chenopodium album L. and Digitaria sanguinalis (L.) Scop. (Ghanizadeh \& Harrington 2019; Buddenhagen et al. 2020, 2021). Atrazine-resistant Chenopodium album was the first case of herbicide resistance detected in New Zealand (Rahman et al. 1983). Persicaria maculosa was next reported resistant to atrazine (Rahman \& Patterson 1987). Triazine-resistant Chenopodium album populations in Waikato later also evolved resistance to dicamba (James et al. 2005). Reports of nicosulfuronresistant Digitaria sanguinalis have been confirmed recently in Waikato and Bay of Plenty (Buddenhagen et al. 2021). Other weed species present in maize have become resistant in other crops, for example Solanum nigrum L. in peas in Manawatu (Harrington et al. 2001). Despite a long history of research, there has not been a systematic herbicide-resistance survey in maize, so the prevalence of resistant weeds in New Zealand maize farms is not wellknown. Certain weed species appear to evolve resistance more often than others (Holt et al. 2013), and within some herbicide modes of action than others (Heap 2014). Many weed species present in maize crops in New Zealand are well represented in a global database of herbicide-resistant weeds (Heap 2021). We use these data and a previously developed protocol (Ngow et al. 2020) to estimate the risk that maize weeds in New Zealand will evolve herbicide resistance.

\section{MATERIALS AND METHODS}

\section{Species list}

A list of weed species was constructed, based primarily on an earlier list compiled by Rahman (1985), and cross validated against more recent sources (e.g., (James et al. 2006, 2015; Rahman et al. 2006) including grey literature (e.g., Foundation for Arable Research, 2013). Only weeds growing primarily in the summer season were included, and coolseason weeds like $\mathrm{C}_{3}$ grasses (e.g., Bromus catharticus Vahl and Lolium spp.), and primarily winter- and spring-active broadleaf species (e.g., Stellaria media (L.) Vill., Veronica spp. and Lepidium didymum L.) were excluded. Also excluded are uncommon weeds (e.g., Amaranthus viridis L.) and "firstyear-out-of-pasture" weeds (e.g., Ranunculus acris L.) but the high priority regulated weeds Abutilon theophrasti Medik. and Xanthium strumarium L. are included. Nomenclature follows the Flora of New Zealand Online (Breitwieser et al. 2010), and authorities and scientific names are listed in Table 2 . 
Table 2. List of 39 species identified as being occurring in New Zealand maize crops.

\begin{tabular}{|c|c|c|c|c|c|}
\hline No. & Species & Common Name $^{1}$ & Family & Growth Form & Citation \\
\hline 1 & Abutilon theophrasti Medik. & velvetleaf & Malvaceae & annual forb & (James \& Pene 2018) \\
\hline 2 & Amaranthus blitum ssp oleraceus (L.) Costea & purple amaranth & Amaranthaceae & annual forb & Author observation \\
\hline 3 & Amaranthus powellii S.Watson & redroot & Amaranthaceae & annual forb & (Rahman 1985) \\
\hline 4 & Bidens frondosa $\mathrm{L}$. & beggars' ticks & Asteraceae & annual forb & (James et al. 2015) \\
\hline 5 & Calystegia sepium ssp roseata Brummitt & pink bindweed & Convulvulaceae & perennial vine & (James et al. 2006) \\
\hline 6 & Calystegia silvatica ssp disjuncta Brummitt & great bindweed & Convulvulaceae & perennial vine & (Rahman 1985) \\
\hline 7 & Chenopodium album L. & fathen & Amaranthaceae & annual forb & (Rahman 1985) \\
\hline 8 & Cirsium arvense (L.) Scop. & California thistle & Asteraceae & perennial forb & (Rahman 1985) \\
\hline 9 & Conium maculatum L. & hemlock & Apiaceae & annual/biennual forb & (James et al. 2007) \\
\hline 10 & Cynodon dactylon (L.) Pers. & Indian doab & Poaceae & perennial graminoid & (Rahman 1985) \\
\hline 11 & Cyperus rotundus L. & purple nutsedge & Cyperaceae & perennial graminoid & (Rahman et al. 1998) \\
\hline 12 & Datura stramonium L. & thorn apple & Solanaceae & annual forb & (Rahman 1985) \\
\hline 13 & Digitaria sanguinalis (L.) Scop. & summer grass & Poaceae & annual graminoid & (Rahman 1985) \\
\hline 14 & Echinochloa crus-galli (L.) P.Beauv. & barnyard grass & Poaceae & annual graminoid & (Rahman 1985) \\
\hline 15 & Eleusine indica (L.) Gaertn. & crowfoot grass & Poaceae & annual graminoid & (Rahman 1985) \\
\hline 16 & Elytrigia repens (L.) Nevski & couch/twitch & Poaceae & perennial graminoid & (Rahman 1985) \\
\hline 17 & Fallopia convolvulus (L.) Á.Löve & cornbind & Polygonaceae & annual vine & (FAR, 2013) \\
\hline 18 & Galinsoga parviflora Cav. & galinsoga & Asteraceae & annual forb & Author observation \\
\hline 19 & Malva parviflora $\mathrm{L}$. & $\begin{array}{l}\text { small-flowered } \\
\text { mallow }\end{array}$ & Malvaceae & annual forb & (Rahman et al. 2006) \\
\hline 20 & Modiola carioliana (L.) G.Don & creeping mallow & Malvaceae & $\begin{array}{l}\text { annual/perennial } \\
\text { forb }\end{array}$ & Author observation \\
\hline 21 & Nicandra physalodes (L.) Gaertn. & apple of Peru & Solanaceae & annual forb & (James et al. 2007) \\
\hline 22 & Oxalis latifolia Kunth $^{2}$ & $\begin{array}{l}\text { fishtail oxalis and } \\
\text { pink shamrock }{ }^{2}\end{array}$ & Oxalidaceae & perennial forb & (FAR, 2013) \\
\hline 23 & Panicum capillare L. & witchgrass & Poaceae & annual graminoid & (FAR, 2013) \\
\hline 24 & Panicum dichotomiflorum Michx. & smooth witchgrass & Poaceae & annual graminoid & (Rahman 1985) \\
\hline 25 & Panicum miliaceum L. & broomcorn millet & Poaceae & annual graminoid & (James et al. 2010) \\
\hline 26 & Paspalum distichum $\mathrm{L}$. & Mercer grass & Poaceae & perennial graminoid & (Rahman 1985) \\
\hline 27 & Persicaria hydropiper (L.) Spach & waterpepper & Polygonaceae & annual forb & (Rahman 1985) \\
\hline 28 & Persicaria lapathifolia (L.) Gray & pale willow weed & Polygonaceae & annual forb & Author observation \\
\hline 29 & Persicaria maculosa Gray & willow weed & Polygonaceae & annual forb & (Rahman 1985) \\
\hline 30 & Polygonum aviculare L. & wireweed & Polygonaceae & annual forb & (Rahman et al. 2004) \\
\hline 31 & Portulaca oleracea L. & purslane & Portulacaceae & annual forb & (Rahman et al. 2004) \\
\hline 32 & Rumex obtusifolius L. & broadleaf dock & Polygonaceae & perennial forb & (Rahman 1985) \\
\hline 33 & Rumex pulcher L. & fiddle dock & Polygonaceae & perennial forb & Author observation \\
\hline 34 & Setaria pumila (Poir)) Roem. \& Schult. & yellow bristle grass & Poaceae & annual graminoid & (James et al. 2015) \\
\hline 35 & Setaria verticillata (L.) P.Beauv. & rough bristle grass & Poaceae & annual graminoid & (Rahman 1985) \\
\hline 36 & Solanum americanum Mill. & $\begin{array}{l}\text { small-flowered } \\
\text { nightshade }\end{array}$ & Solanaceae & annual forb & Author observation \\
\hline 37 & Solanum nigrum L. & black nightshade & Solanaceae & annual forb & (Rahman 1985) \\
\hline 38 & Xanthium spinosum L. & Bathurst bur & Asteraceae & annual forb & Author observation \\
\hline 39 & Xanthium strumarium L. & Noogoora bur & Asteraceae & annual forb & (Rahman 1985) \\
\hline
\end{tabular}

${ }^{1}$ Common names obtained from Nicol 1997.

${ }^{2}$ The common name "pink shamrock" is associated with the species Oxalis vallicola (Rose) R.Knuth and is listed as a synonym of Oxalis latifolia Kunth in the Flora of New Zealand Online, however the name Oxalis vallicola is used in some sources, e.g. https://www.massey.ac.nz/massey/learning/colleges/collegeof-sciences/clinics-and-services/weeds-database/pink-shamrock.cfm 


\section{Ranking herbicide groups and species by resistance cases}

The method of ranking herbicide groups and weed species has been described previously (Ngow et al. 2020), and is adapted from previous herbicide resistance risk assessment tools (EPPO, 2015; Moss et al. 2019). The analyses rely on data from the International Survey for Herbicide Resistant Weeds (Heap 2021) and the Herbicide Resistance Action Committee system (HRAC 2021) for classifying modes of action for individual herbicide active ingredients. The method accounts for not only the level of risk for each modeof-action based on the number of species with resistance worldwide but also for weed species based on the number of documented cases of evolved resistance in each weed species. The herbicide mode-of-action risk scoring system and the risk scores were the same as those of Ngow et al. (2020). The species-risk scores were determined using the number of resistance cases from the International Survey of Herbicide Resistant Weeds (Heap 2021); here, cases were defined as a record of herbicide resistance for a weed species to any mode of action. Risk scores were designated as $\geq 10$ cases for high risk (score $=3$ ), $<10$ for moderate (score $=2$ ) and no cases recorded as low risk (score $=1$ ).

As an example, there are 13 cases of herbicide resistance for Digitaria sanguinalis across three modes of action, for a high species risk score of 3 (Table 3). The herbiciderisk scores for HRAC herbicide groups in which Digitaria sanguinalis has evolved resistance were then examined. There are cases in two herbicide modes of action used in maize, acetohydroxyacid synthase inhibitors (HRAC group 2; AHAS) and photosystem-II inhibitors (HRAC group 3; PS-II), each with $>9 \%$ of all resistance cases so the risk score here is also 3. There are also seven cases of Digitaria sanguinalis becoming resistant to acetyl-coenzyme-A carboxylase inhibitors (HRAC group 1; ACCase) - a herbicide group that presents a high risk of resistance. However, that herbicide group is not used in maize so it was omitted from the maize total. The two different herbicide risk scores were added, then multiplied by the species "inherent" risk to obtain a total species risk score $((3+3) \times 3=18)$.

This total risk score incorporates the mode-of-action risk score for herbicides used in New Zealand maize (Table 1 ). The number of cases of herbicide resistance for each species that has at least one resistance case by mode of action is provided in Table 3. Of the total risk score, the risk component attributable to maize is shown as an orange bar based on those herbicides used in maize in New Zealand while the component of risk for herbicides not normally used in maize fields is shown as a black bar (Fig 1). Graphs were generated in ggplot2 and tidyverse, both packages in the R statistical platform (Wickham 2016; Wickham et al. 2019; R Core Team 2020).

\section{RESULTS}

We identified 39 weed species associated with maize in New Zealand (Table 2). Seven species were classified as highrisk (total cases > 10), in order of cases: Echinochloa crusgalli (L.) P.Beauv. (11 in maize and 63 total), Chenopodium album $(36,52)$, Eleusine indica (L.) Gaertn. $(8,44)$, Xanthium strumarium $(1,20)$, Amaranthus powellii S.Watson $(6,16)$, Solanum nigrum $(8,14)$ and Digitaria sanguinalis $(3,13)$ (Table 3). There are 17 moderate-risk species $(<10$ total cases $>0$ ) including two Panicum spp., three Persicaria spp. and two Setaria spp. No cases of resistance were found for 15 species so these were classified as low risk. These species are: Conium maculatum L., Bidens frondosa L., Xanthium spinosum L., Calystegia sepium ssp roseata Brummitt, Calystegia silvatica ssp disjuncta Brummitt, Cyperus rotundus L., Malva parviflora L., Oxalis latifolia Kunth, Panicum miliaceum L., Cynodon dactylon (L.) Pers., Paspalum distichum L., Elytrigia repens (L.) Nevski, Rumex pulcher L. and Nicandra physalodes (L.) Gaertn. Of these lowrisk species, eight are perennial species with principally vegetative reproduction (Table 2).

Cases of herbicide resistance for the listed species, for each mode of action (HRAC 2021) are shown in Table 3. Two herbicide mode of action groups are at high risk of selecting for weeds with resistance: acetohydroxyacid synthase inhibitors (group 2; e.g., nicosulfuron); and photosystem-II inhibitors (group 5; e.g., atrazine). A third group, synthetic auxins (group 4; e.g., dicamba) was classified as moderate risk. All other herbicide groups registered for maize in New Zealand are classified as low risk, including the commonly used herbicides acetochlor (group 15), pendimethalin (group 3), saflufenacil (group 14), topramezone (group 27) and mesotrione (group 27).

The weed species that generated the highest scores for potential herbicide resistance had globally documented cases of resistance to photosystem-II inhibitors (HRAC group 5; 114 cases) and/or acetohydroxyacid synthase inhibitors (group 2; 59 cases). Ten cases or less were reported for either microtubule assembly inhibitors (group 3 ) or synthetic auxins (group 4) and less than five cases for protoporphyrinogen oxidase inhibitors (group 14; PPO) or very long-chain fatty-acid synthesis inhibitors (group 15; VLCFA). None of the listed weeds were reported to have evolved resistance to hydroxyphenyl pyruvate dioxygenase inhibitors (group 27; HPPD).

The five weeds with the highest total risk scores are Echinochloa crus-galli, Eleusine indica, Chenopodium album, Digitaria sanguinalis, Amaranthus powellii (Figure 1). Two species with previous cases of resistance in New Zealand (Chenopodium album and Digitaria sanguinalis) are in the top five ranked weeds. Solanum nigrum and Xanthium strumarium were not placed high in the total risk ranking because many of the globally documented cases of resistance were to herbicides not used in maize. Eleusine indica and Echinochloa crus-galli had the highest risk of resistance against herbicides used in maize, but both also have many documented cases of evolved resistance to herbicides not used in maize.

\section{DISCUSSION}

The risk scores calculated here appear to have some predictive value, given that some high-risk weeds (Chenopodium album, Solanum nigrum and Digitaria sanguinalis) have already been found to be resistant in New Zealand in maize or other crops. A similar outcome 


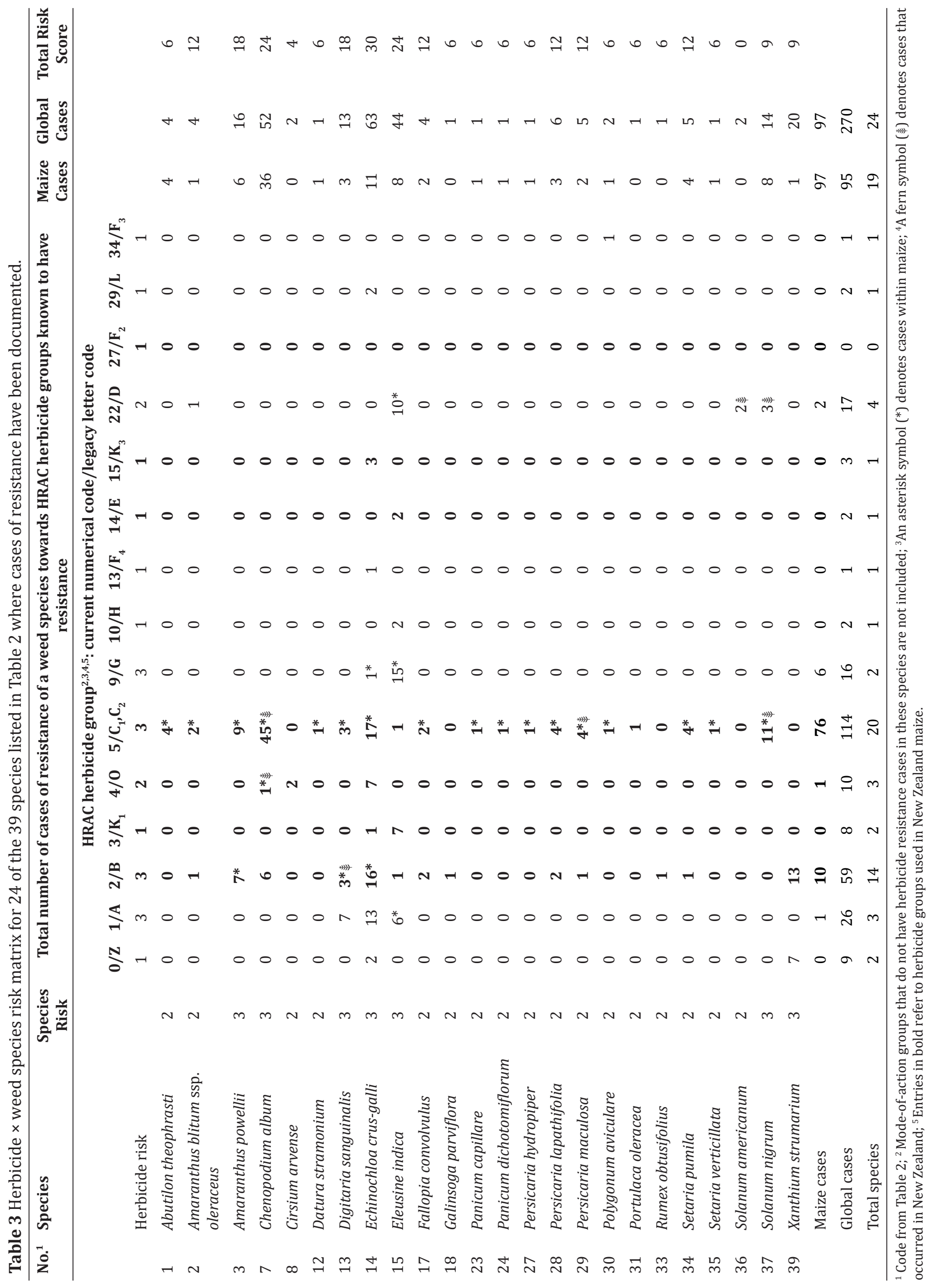



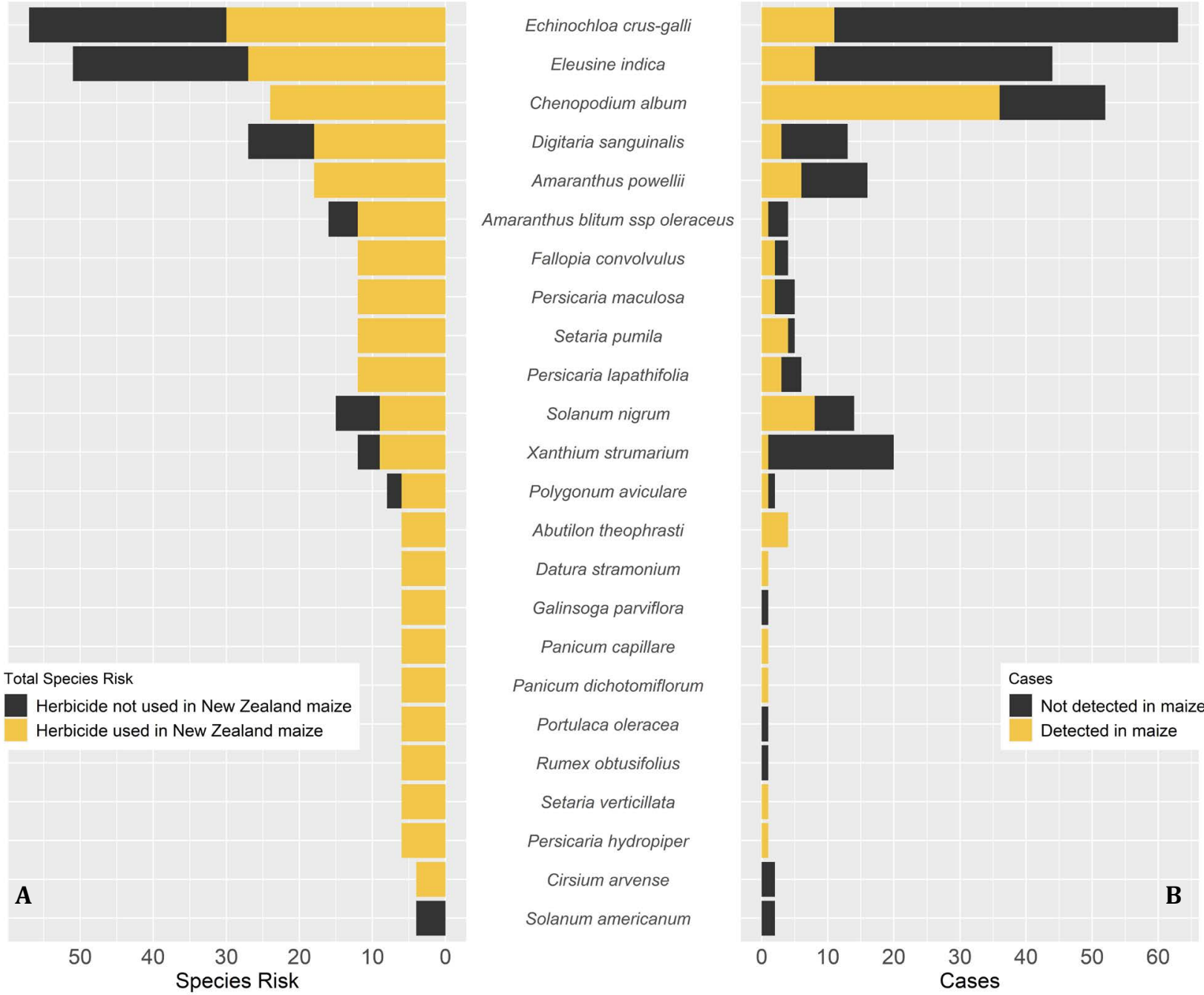

Figure 1 Detailed risk and case data for the 24 maize weeds classified as high or moderate risk of developing herbicide resistance in New Zealand. A: overall risk score of a weed species evolving herbicide resistance. High risk score: >10; moderate risk score: $<10$ but $>0$. B: number of published cases of herbicide resistance. Note: cases of resistance in non-maize crops can still be toward herbicide groups used in maize.

was seen in the risk assessment carried out for wheat and barley (Ngow et al. 2020). Weed species already resistant to at least one herbicide mode of action are at risk of becoming multiply resistant. Chenopodium album already has multiple resistance to herbicides from the triazine (i.e. atrazine) and synthetic auxin (i.e., dicamba, picloram) groups (James et al. 2005; Ghanizadeh \& Harrington 2017), and has a high risk of developing resistance to acetohydroxyacid synthase inhibitors, as highlighted by recent cases of resistance in China (Huang et al. 2020) and Canada (Mo 2021). Despite widespread resistance globally for the weed species Echinochloa crus-galli, Amaranthus powellii and Eleusine indica there have not been any reports of resistance in New Zealand to date.

Only two high-risk herbicide mode-of-action groups (AHAS, PS-II inhibitors) and one moderate-risk group (synthetic auxins) are widely used in maize in New Zealand (Table 3). Most weed species ranked highly on this list have cases of resistance from either of these two high-risk groups. Eleusine indica is an exception - it is ranked second for total risk score (Figure 1), yet most resistance cases are in herbicides not widely used in maize. This species and
Echinochloa crus-galli are the only species on this list to have evolved resistance to the low-risk herbicide groups used in maize (Table 3).

The weeds classified as high risk of becoming resistant are all annual forbs or grasses. Two perennial weed species Rumex obtusifolius L. and Cirsium arvense (L.) Scop. have a moderate risk, but the remaining eight perennial species listed in Table 2 are low risk. However, some of these weeds have been reported to possess a natural tolerance to herbicides, such as Oxalis latifolia and Calystegia sepium ssp. roseata (Rahman et al. 2002). Some herbicides are not expected to control certain taxonomic groups of weeds, e.g., ACCase inhibitors control grasses and Geraniaceae but not most other eudicots (Délye 2005). Overseas, atrazine can be used at high rates that permit control of Digitaria sanguinalis, although resistance cases are known (e.g., YanHui et al. 2017). In New Zealand, the label rates of atrazine are not sufficient to control Digitaria sanguinalis and other grass weeds. Cyperus rotundus is a common weed (Rahman et al. 1998) that is ranked as low risk here as it has never been reported as herbicide-resistant anywhere. Despite its low risk, it is difficult to control and only one 
herbicide is registered for its control in New Zealand. The propensity of a species to become herbicide resistant does not necessarily indicate that it is more problematic than other lower-risk species, nor does a low risk of developing resistance indicate the species is less problematic. Eleusine indica is a high-risk weed that is not often cited as a major problem in maize in New Zealand, yet it might become one if it evolves herbicide resistance.

Abutilon theophrasti and Xanthium strumarium are two uncommon, high-priority regulated weeds with moderateand high-risk rankings respectively. Abutilon theophrasti, a quarantine weed, had two recent incursions in New Zealand, one in Waikato before 2011 and then across the country in 2015. It was introduced as a contaminant in imported Italian fodder beet seed (James \& Cooper 2012, James \& Pene 2018). Only four cases of resistance of this weed have been reported, all in maize crops and all toward atrazine in the United States (Anderson \& Gronwald 1991). It is notable that some New Zealand Abutilon theophrasti populations were not controlled by high rates of atrazine (James \& Cooper 2012). Although maize seed for sowing is rarely contaminated, other crops such as brassica may provide a pathway for the introduction of more common maize weeds i.e., Chenopodium, Echinochloa, Persicaria, Amaranthus in other crops, which may be herbicide resistant (Rubenstein et al. 2021). Seed for sowing could also bring in highly resistant species such as Amaranthus palmerii S.Watson and Amaranthus tuberculatus (Moq.) Sauer, neither of which are on the New Zealand quarantine weed list (MPI 2018).

This study does not account for the actual abundance of weeds, or herbicide use at the field level. High weed abundance in a field increases the likelihood of a population evolving herbicide resistance (Jasieniuk et al. 1996), and prevalence across regions in a weed species was identified as a predictor of herbicide resistance (Hulme \& Liu 2021). Clearly herbicide use patterns affect the probability of resistance developing; unlike the wheat and barley risk assessment (Ngow et al. 2020), we do not have current data of herbicide field applications in maize. More insightful analysis of herbicide resistance risk would be possible if maize growers were to use an online platform for recording herbicide use. Our analysis may underestimate the risk for recently adopted mode-of-action groups with fewer reported cases of resistance documented. For example, HPPD inhibitors (mesotrione and topramezone) and PPO inhibitors (saflufenacil) were introduced to the market in the 2000s (Almsick 2009; Grossmann et al. 2010). Our risk assessment method relies on data that may contain biases that reflect regional differences in herbicide use, herbicide availability, resistance reporting and scientific attention.

Repeated use of any given method of weed control should be avoided where possible. Exposure over many years to a herbicide with a particular mode of action increases the likelihood of selecting plants with a resistance conferring mutation (Jasieniuk et al. 1996). Busi et al. (2020) found that pre-emergent herbicides, complex rotation between modesof-action, and mixtures of these herbicides delay the onset of herbicide resistance. These practices can be followed for maize as there are several pre-emergent and postemergent herbicide options (Table 1). Cultural practices of delayed planting, crop rotation, harvest weed-seed control, targeted tillage, increasing crop competitiveness and cover cropping can mitigate the evolution of herbicide resistance (Mhlanga et al. 2016; Trolove et al. 2017; Somerville et al. 2018; Moss et al. 2019; Walsh et al. 2020). Such integrated weed management techniques have long been promoted as a solution to herbicide resistance in weeds (Norsworthy et al. 2012; Harker 2013; Beckie et al. 2019; Moss et al. 2019).

\section{CONCLUSIONS}

Maize weeds in New Zealand are at a high risk of developing resistance to acetohydroxyacid synthase inhibitors (group 2) and photosystem-II inhibitors (group 5). Repeated selection for herbicide resistance is well documented internationally in the seven high-risk species, Echinochloa crus-galli, Chenopodium album, Eleusine indica, Xanthium strumarium, Amaranthus powellii, Solanum nigrum and Digitaria sanguinalis. Herbicide resistance surveys should focus on these high-risk weed species and herbicides. Extension efforts could help agrichemical suppliers, farmers and agronomists to preserve the efficacy of currently used herbicides by practising integrated weed management.

\section{ACKNOWLEDGEMENTS}

This work was funded by the Endeavour fund (C10X1806, Improved weed control and vegetation management to minimise future herbicide resistance) from the New Zealand Ministry for Business, Innovation and Employment. We thank Ian Heap for access to the data necessary for this analysis. We thank Phil Rolston, Claire Mills, Mike Dodd, Shona Lamoureaux and two anonymous reviewers for their valuable comments to improve this manuscript.

\section{REFERENCES}

AIMI 2020. New Zealand survey of maize areas and volumes. Arable Industry Marketing Initiative, New Zealand. https://www.far.org.nz/

Almsick A 2009. New HPPD-Inhibitors - A proven mode of action as a new hope to solve current weed problems. Outlooks on Pest Management 20: 27-30. https://doi. org/10.1564/20feb09

Anderson MP, Gronwald JW 1991. Atrazine resistance in a velvetleaf (Abutilon theophrasti) biotype due to enhanced glutathione S-transferase activity. Plant Physiology 96: 104-109. https://doi.org/10.1104/ pp.96.1.104

Beckie HJ, Ashworth MB, Flower KC 2019. Herbicide resistance management: recent developments and trends. Plants 8: 161. https://doi.org/10.3390/ plants8060161

Booker JW 2009. Production, distribution and utilisation of maize in New Zealand. Lincoln University, Lincoln, New Zealand.

Breitwieser I, Brownsey PJ, Heenan PB, Nelson WA, Wilton AD 2010. Flora of New Zealand Online. Landcare Research Manaaki Whenua, New Zealand. http://www. nzflora.info/ 
Buddenhagen CE, Gunnarsson M, Rolston P, Chynoweth RJ, Bourdôt G, James TK 2020. Costs and risks associated with surveying the extent of herbicide resistance in New Zealand. New Zealand Journal of Agricultural Research 63: 430-448. https://doi.org/10.1080/00288233.2019 .1636829

Buddenhagen CE, James TK, Ngow Z, Hackell DL, Rolston MP, Chynoweth RJ, Gunnarsson M, Li F, Harrington KC, Ghanizadeh H 2021. Resistance to post-emergent herbicides is becoming common for grass weeds on New Zealand wheat and barley farms. PLOS ONE 16: e0258685. https://doi.org/10.1371/journal. pone. 0258685

Busi R, Powles SB, Beckie HJ, Renton M 2020. Rotations and mixtures of soil-applied herbicides delay resistance. Pest Management Science 76: 487-496. https://doi. org/10.1002/ps.5534

Délye C 2005. Weed resistance to acetyl coenzyme A carboxylase inhibitors: an update. Weed Science 53: 728-746. https://doi.org/10.1614/WS-04-203R.1

Délye C, Jasieniuk M, Le Corre V 2013. Deciphering the evolution of herbicide resistance in weeds. Trends in Genetics 29: 649-658. https://doi.org/10.1016/j. tig.2013.06.001

EPPO, 2015. PP 1/213 (4) Resistance risk analysis. EPPO Bulletin 45: 371-387. https://doi.org/10.1111/ epp.12246

FAO, 2021. Production Indices. FAOSTAT, Rome, Italy. http:// www.fao.org/faostat/en/\#data/QI

FAR, 2013. FAR Focus 11: Weed Management for Maize. Foundation for Arable Research, New Zealand. https:// www.far.org.nz/assets/files/uploads/FAR Focus 11 weeds_in_maize.pdf

FAR, 2020. FAR Research Results 2018/2019. Foundation for Arable Research, New Zealand. https://www.far.org. nz/assets/files/blog/files//dfd1b8c8-654d-527f-91f0$\underline{00 \mathrm{e} 2 \mathrm{ef5} 5 \mathrm{~d} 0 \mathrm{a} 4 . \mathrm{pdf}}$

Ghanizadeh H, Harrington KC 2017. Cross-resistance to auxinic herbicides in dicamba-resistant Chenopodium album. New Zealand Journal of Agricultural Research 60: 45-53. https://doi.org/10.1080/00288233.2016.1 $\underline{238397}$

Ghanizadeh H, Harrington KC 2019. Herbicide resistant weeds in New Zealand: state of knowledge. New Zealand Journal of Agricultural Research 64: 471-482. https:// doi.org/10.1080/00288233.2019.1705863

Grossmann K, Niggeweg R, Christiansen N, Looser R, Ehrhardt T 2010. The herbicide saflufenacil (Kixor ${ }^{\mathrm{TM}}$ ) is a new inhibitor of protoporphyrinogen IX oxidase activity. Weed Science 58: 1-9. https://doi.org/10.1614/ WS-D-09-00004.1

Harker KN 2013. Slowing weed evolution with integrated weed management. Canadian Journal of Plant Science. https://doi.org/10.4141/cjps2013-049

Harrington KC, Ward AJ, Wells DM 2001. Herbicide resistance in black nightshade and Onehunga weed. New Zealand Plant Protection 54: 152-156. https://doi. org/10.30843/nzpp.2001.54.3713

Heap I 2014. Global perspective of herbicide-resistant weeds. Pest management science 70: 1306-1315. https://doi.org/10.1002/ps.3696

Heap I 2021. International Survey of Herbicide Resistant Weeds - www.weedscience.org

Holt JS, Welles SR, Silvera K, Heap IM, Heredia SM, MartinezBerdeja A, Palenscar KT, Sweet LC, Ellstrand NC 2013. Taxonomic and life history bias in herbicide resistant weeds: implications for deployment of resistant crops. PLOS ONE 8: e71916. https://doi.org/10.1371/journal. pone.0071916

HRAC 2021. Herbicide Resistance Action Committee. https://hracglobal.com/

Huang Z, Zhou X, Zhang C, Jiang C, Huang H, Wei S 2020. First report of molecular basis of resistance to imazethapyr in common lambsquarters (Chenopodium album). Weed Science 68: 63-68. https://doi.org/10.1017/ wsc.2019.62

Hulme PE, Liu W 2021. Species prevalence and plant traits discriminate between herbicide resistant and susceptible weeds. Pest Management Science: In press. https://doi.org/10.1002/ps.6636

James TK, Cooper JM 2012. Control of the recently introduced weed butterprint (Abutilon theophrasti) in maize. New Zealand Plant Protection 65: 64-68. https:// doi.org/10.30843/nzpp.2012.65.5426

James T, Dowsett C, Trolove M 2015. Identification and enumeration of weed seeds in chopped maize being transported for silage. New Zealand Plant Protection 68: 118-123. https://doi.org/10.30843/ nzpp.2015.68.5879

James TK, Pene HM 2018. Abutilon theophrasti - its biology and management in New Zealand. Weed Society of New South Wales Inc. 21st Australasian Weeds Conference," Weed Biosecurity-Protecting our Future", Sydney, New South Wales, Australia, 9-13 September 2018: 27-31.

James TK, Rahman A, Hicking J 2006. Mesotrione a new herbicide for weed control in maize. New Zealand Plant Protection 59: 242-249. https://doi.org/10.30843/ nzpp.2006.59.4403

James T, Rahman A, Meilsop JM 2005. Fathen (Chenopodium album) a biotype resistant to dicamba. NewZealand Plant Protection 58: 152-156. https://doi.org/10.30843/ nzpp.2005.58.4321

James TK, Rahman A, Trivedi PD 2010. Broom corn millet (Panicum miliaceum): a new menace for maize and sweetcorn growers in New Zealand. Proc. 17th Australasian Weeds Conf., Christchurch, New Zealand: 32-35.

James TK, Rahman A, Trolove M 2007. Optimising time of planting and herbicide application for control of problem weeds in maize. New Zealand Plant Protection 60: 183188. https://doi.org/10.30843/nzpp.2007.60.4598

Jasieniuk M, Brûlé-Babel AL, Morrison IN 1996. The evolution and genetics of herbicide resistance in weeds. Weed Science 44: 176-193. https://doi.org/10.1017/ 


\section{S0043174500093747}

Mhlanga B, Chauhan BS, Thierfelder C 2016. Weed management in maize using crop competition: A review. Crop Protection 88: 28-36. https://doi.org/10.1016/j. cropro.2016.05.008

Mo C 2021. Characterisation of resistance to ALS inhibitors in Chenopodium album (L.) populations in Ontario. University of Guelph, Ontario, Canada

Morris NJ, Hurley TD, Densley RJ 2016. National and regional maize grain and silage strip trial yields. Journal of New Zealand Grasslands 78: 157-162. https://doi. org/10.33584/jnzg.2016.78.510

Moss S, Ulber L, den Hoed I 2019. A herbicide resistance risk matrix. Crop Protection 115: 13-19. https://doi. org/10.1016/j.cropro.2018.09.005

MPI, 2018. Schedule of regulated (quarantine) weed seeds. Ministry for Primary Industries. https://www.mpi. govt.nz/dmsdocument/7111-schedule-of-regulatedquarantine-weed-seeds

Ngow Z, Chynoweth RJ, Gunnarsson M, Rolston P, Buddenhagen CE 2020. A herbicide resistance risk assessment for weeds in wheat and barley crops in New Zealand. PLOS ONE 15: e0234771. https://doi. org/10.1371/journal.pone.0234771

Nicol ER 1997. Common names of plants in New Zealand. Manaaki Whenua Press.

Norsworthy JK, Ward SM, Shaw DR, Llewellyn RS, Nichols RL, Webster TM, Bradley KW, Frisvold G, Powles SB, Burgos NR, Witt WW, Barrett M 2012. Reducing the risks of herbicide resistance: best management practices and recommendations. Weed Science 60: 31-62. https://doi. org/10.1614/WS-D-11-00155.1

Oerke E-C 2006. Crop losses to pests. The Journal of Agricultural Science 144: 31-43. https://doi. org/10.1017/S0021859605005708

Page ER, Cerrudo D, Westra P, Loux M, Smith K, Foresman C, Wright H, Swanton CJ 2012. Why early season weed control is important in maize. Weed Science 60: 423430. https://doi.org/10.1614/WS-D-11-00183.1

R Core Team 2020. R: A Language and Environment for Statistical Computing. R Foundation for Statistical Computing, Vienna, Austria. https://www.R-project. org/

Rahman A 1985. Weed control in maize in New Zealand. Special Publication, Agronomy Society of New Zealand: 37-45. https://doi.org/10.30843/nzpp.1984.37.9549

Rahman A, James TK, Grbavac N 2006. Correlation between the soil seed bank and weed populations in maize fields. Weed Biology and Management 6: 228-234. https://doi. org/10.1111/j.1445-6664.2006.00223.x

Rahman A, James TK, Mellsop JM, Grbavac N 2004. Predicting broadleaf weed populations in maize from the soil seedbank. New Zealand Plant Protection 57: 281-285. https://doi.org/10.30843/nzpp.2004.57.6973

Rahman A, James TK, Mellsop JM, Pyke N 2002. Management of Oxalis latifolia and Calystegia sepium in maize. New
Zealand Plant Protection 55: 235-240. https://doi. org/10.30843/nzpp.2002.55.3896

Rahman A, James TK, Sanders P, Lane M 1998. Halosulfuron for selective control of purple nutsedge in maize. Proceedings of the New Zealand Plant Protection Conference 51: 84-89. https://doi.org/10.30843/ nzpp.1998.51.11655

Rahman A, Patterson TM 1987. Polygonum persicaria - a triazine-resistant biotype. Proceedings of the 40th New Zealand Weed and Pest Control Conference: 186-188. https://doi.org/10.30843/nzpp.1987.40.9933

Rahman A, T.k J, Mortimer J 1983. Control of atrazineresistant fathen in maize. Proceedings of the 36th New Zealand Weed and Pest Control Conference: 229-232. https://doi.org/10.30843/nzpp.1983.36.9582

Robertson N, Hurren K 2019. Arable Production 2018 - Economic impact assessment. Business and Economic Research. http://www.uwg.co.nz/content/ documents /2019\%20September $\% 206 \% 20$ AFIC $\% 20$ Arable\%20Production\%20Final.pdf

Rubenstein JM, Hulme PE, Buddenhagen CE, Rolston MP, Hampton JG 2021. Weed seed contamination in imported seed lots entering New Zealand. PLOS ONE 16: 1-13. https://doi.org/10.31220/agriRxiv.2021.00057

Somerville GJ, Powles SB, Walsh MJ, Renton M 2018. Modeling the impact of harvest weed seed control on herbicide-resistance evolution. Weed Science 66: 395403. https://doi.org/10.1017/wsc.2018.9

Trolove MR, James TK, Holmes AW, Parker MD, McDougall SJ, Pirie MR 2017. Winter cover crops to reduce herbicide inputs in maize crops. New Zealand Plant Protection 70: 171-178. https://doi.org/10.30843/nzpp.2017.70.46

Walsh MJ, Squires CC, Coleman GRY, Widderick MJ, McKiernan AB, Chauhan BS, Peressini C, Guzzomi AL 2020. Tillage based, site-specific weed control for conservation cropping systems. Cambridge University Press. Weed Technology 34: 704-710. https://doi. org/10.1017/wet.2020.34

Wickham H 2016. ggplot2: Elegant Graphics for Data Analysis. Springer-Verlag New York. http://ggplot2.org. https://doi.org/10.1007/978-3-319-24277-4

Wickham H, Averick M, Bryan J, Chang W, McGowan LD, François R, Grolemund G, Hayes A, Henry L, Hester J, Kuhn M, Pedersen TL, Miller E, Bache SM, Müller K, Ooms J, Robinson D, Seidel DP, Spinu V, Takahashi K, Vaughan D, Wilke C, Woo K, Yutani H 2019. Welcome to the tidyverse. Journal of Open Source Software 4: 1686. https://doi.org/10.21105/joss.01686

YanHui W, CaiYing Y, YongLin M, HuiYe H, ChengLin G, JianLin Q, YueFeng M 2017. Resistance level and mechanisms of Digitaria sanguinalis to atrazine in sugarcane field of Guangxi. Southwest China Journal of Agricultural Sciences 30: 1790-1794. 